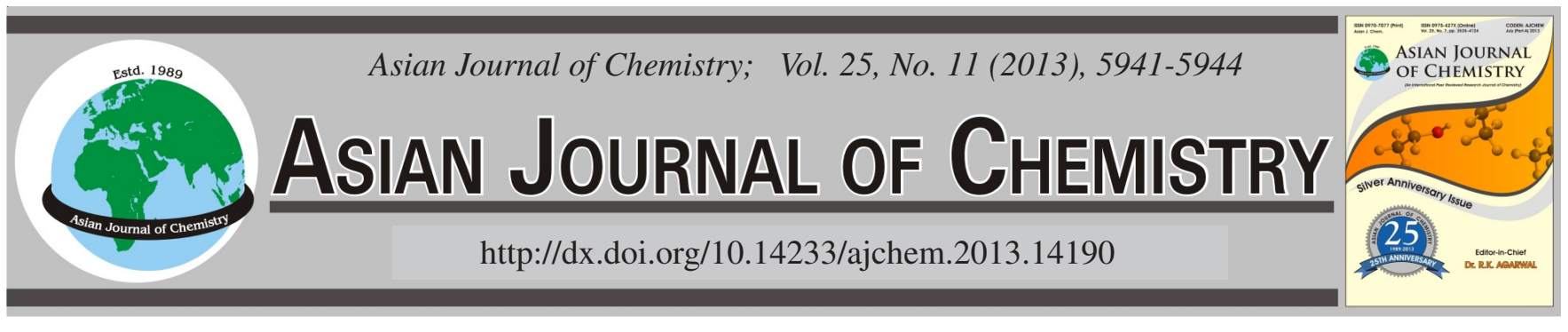

\title{
Chemistry of Groundwater from the Taiyuan Formation Aquifer in Liuyi Coal Mine, Northern Anhui Province, China and Its Implications for Water Rock Interaction in Deep Seated Environment
}

\author{
H.R. GuI ${ }^{*}$ and L.H. SuN
}

School of Earth Science and Engineering, Suzhou University, Suzhou, P.R. China

*Corresponding author: Fax: +86 557 3685692; Tel: +86 557 2871038; E-mail: guiherong@163.com

\begin{abstract}
Chemical compositions of groundwater from the Taiyuan formation aquifer in Liuyi coal mine, Northern Anhui Province, China have been measured for evaluating the hydro-chemical evolution in deep environments. The total dissolved solids values of groundwater range from 640 to $2567 \mathrm{mg} / \mathrm{L}$ and indicates moderate to highly mineralized and the ions are predominantly composed of $(\mathrm{Na}+\mathrm{K}), \mathrm{Ca}$ and $\mathrm{SO}_{4}$ with their average concentrations are 225,117 and $508 \mathrm{mg} / \mathrm{L}$, respectively. The groundwater samples are saturated with calcite and dolomite and undersaturated with gypsum with their average saturation indexes are $0.25,0.18$ and -1.29 , respectively. The main minerals incorporated in the water rock interaction include halite, albite, K-feldspar, gypsum, pyrite, calcite and dolomite: Na and K are originated from the dissolution of halite, albite and $\mathrm{K}$-feldspar, $\mathrm{SO}_{4}$ is from dissolution of gypsum and the dissolution and oxidation of pyrite, whereas $\mathrm{Ca}$ and $\mathrm{Mg}$ are originated from dissolution of calcite and dolomite.
\end{abstract}

Key Words: Hydro-geochemistry, Water rock interaction, Groundwater, Deep seated environment.

\section{INTRODUCTION}

Coals and its related products (gas and electronic power) are the main energy in China at the moment. It occupied $60 \%$ of China's primary energy during 2010 and this proportion will maintain more than $50 \%$ till 2050. Therefore, the safety of coal mining is directly related to the development of China's economy. In order to meet the demand of energy consume, more and more attention have been paid towards the deep environments with up to $1000 \mathrm{~m}$ depth as the drying up of coals in shallow areas. In this background, controlling of water inrush in coal mines will become more serious as they can brought to us so many accidents with great losses during mining activities. Take an instance, more than 70 water inrush accidents had occurred from 2007 to 2009 and more than 300 people died.

The controlling of water in rush is based on the knowledge of geological, hydrological conditions of the coal mines, the method for prediction of water in rush probability (geotechnical engineering and geophysical exploration) and water source discrimination (geochemical exploration). Therefore, a series of hydro-chemical studies have been processed and a large number of discrimination models have been reported ${ }^{1-3}$. Although most of these methods were useful in identification the source of water, the reasons about the differences between aquifers have not been well understand.
Previous studies revealed that chemical composition of groundwater is mainly controlled by the supplies (e.g. composition of rainfall) and the geological processes along flow paths (e.g. water rock interactions) within the aquifer ${ }^{4,5}$. Therefore, the water rock interactions have attracted a large number of studies $^{6,7}$. However, similar work related to the deep environments is limited because of the difficulty of sampling.

In this paper, the chemical compositions (major ions) of groundwater from the Taiyuan Formation aquifer (a limestone aquifer) in Liuyi coal mine, northern Anhui Province, China have been measured for evaluating the hydro-chemical characteristics of the aquifer.

\section{EXPERIMENTAL}

Hydrological background: The Liuqiao coal mine district (including Liuyi and Liuer coal mine) is located west to the Huaibei city, northern Anhui Province, China with its longitude between $116^{\circ} 34^{\prime} 07^{\prime \prime}$ and $116^{\circ} 40^{\prime} 24^{\prime \prime}$, latitude between $33^{\circ} 53^{\prime} 33^{\prime \prime}$ and $33^{\circ} 57^{\prime} 54^{\prime \prime}$. The distance between the coal mine and Huaibei City is $12 \mathrm{~km}$. The coal mine district is separated into Liuyi and Liuer coal mine by Tulou and Guxiaoqiao fault in the northwest and is limited by Liuqiao fault in the southeast (Fig. 1). The length and width of the coal mine district are 7 and $1.5-2 \mathrm{~km}$, with a total area of $14.3 \mathrm{~km}^{2}$. More than one million tons of coal can be produced per year since 1981 . 


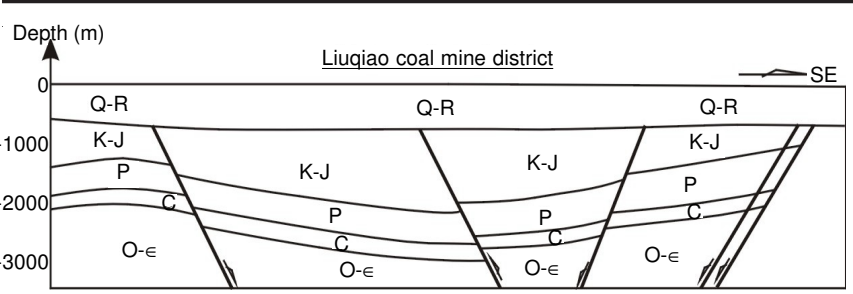

Fig. 1. Cross section of the study area

The coal mine district is covered by Quaternary sediments with huge thickness and the strata revealed by drilling cores include Ordovician, Carboniferous, Permian and Cenozoic with a total thickness of more than $1500 \mathrm{~m}$. The Ordovician strata is composed of thick limestones, the Carboniferous strata is mainly composed of limestones, to a lesser extent, mudstone and sandstone. The Permian strata is mainly composed of mudstone and sandstone without limestone, whereas the Cenozoic strata is composed of clay, mudstone and sandstone. Coals are mainly found in the Permian strata, with limited thin layers can be found in the Carboniferous strata.

Previous investigation ${ }^{8}$ revealed that the groundwater system in the coal mine district is subdivided into four aquifers, including the Quaternary, Coal bearing (Permian), Taiyuan Fm (Carboniferous) and Ordovician limestone aquifers. The Quaternary, Taiyuan Fm and Ordovician aquifers are supplied by precipitation in the north part of the coal mine, whereas the Coal bearing aquifer is relatively "closed" with no obvious supplies from other aquifers.

Methods: A total of 25 groundwater samples for chemical analysis were collected from drainage holes in the alley of Liuyi coal mine during November 2010 and September 2011. Water temperature, $\mathrm{pH}$ and total dissolved solids (TDS) were measured in the field by using a portable $\mathrm{pH}$ and TDS meter. Water samples were filtered through $0.45 \mu \mathrm{m}$ pore-size membrane and collected into $2 \mathrm{~L}$ polyethylene bottles that had been cleaned in the laboratory.

The concentrations of $(\mathrm{Na}+\mathrm{K}), \mathrm{Ca}, \mathrm{Mg}, \mathrm{Cl}, \mathrm{SO}_{4}, \mathrm{HCO}_{3}$ and $\mathrm{CO}_{3}$ concentrations were measured in the laboratory of geochemistry in the Research Center of Coal Exploration, Anhui Province, China. $\mathrm{K}$ and $\mathrm{Na}$ were analyzed by atomic absorption spectrometry, $\mathrm{SO}_{4}$ and $\mathrm{Cl}$ were analyzed by ion chromatography, $\mathrm{Ca}$ and $\mathrm{Mg}$ were analyzed by EDTA titration and alkaline (including $\mathrm{HCO}_{3}$ and $\mathrm{CO}_{3}$ ) was analyzed by Acidbase Titration.

PHREEQC $^{9}$ was used to compute the saturation index (SI) of major minerals (calcite, dolomite and gypsum), which indicates the chemical equilibrium between water and minerals.

\section{RESULTS AND DISCUSSION}

Concentrations and water types: The total dissolved solids (TDS) values of the groundwater samples range from 640-2567 mg/L (Table-1) and indicates moderate to highly mineralized water. The cations are mainly composed of ( $\mathrm{Na}+$ $\mathrm{K}$ ) and $\mathrm{Ca}$, their average concentrations are 225 and $117 \mathrm{mg} /$ $\mathrm{L}$, respectively, whereas the anions is $\mathrm{SO}_{4}$ predominant, with an average value of $508 \mathrm{mg} / \mathrm{L}$. Moreover, these groundwater samples are slightly alkaline as their $\mathrm{pH}$ values range from 7.3 to 8.8 .
Because of their significant variation of chemical compositions, the plots of sample show large span on the Piper diagram (Fig. 2) and can be classified into several types (Table-1) with $\mathrm{Ca} / \mathrm{Na}-\mathrm{SO}_{4}$ predominant. Another phenomenon can also be obtained from Fig. 2 that they show high $\mathrm{HCO}_{3}{ }^{-}$to high $\mathrm{SO}_{4}{ }^{2-}$ and high $(\mathrm{Na}+\mathrm{K})$ to high $\mathrm{Ca}$ trend, probably indicating their multi origins.

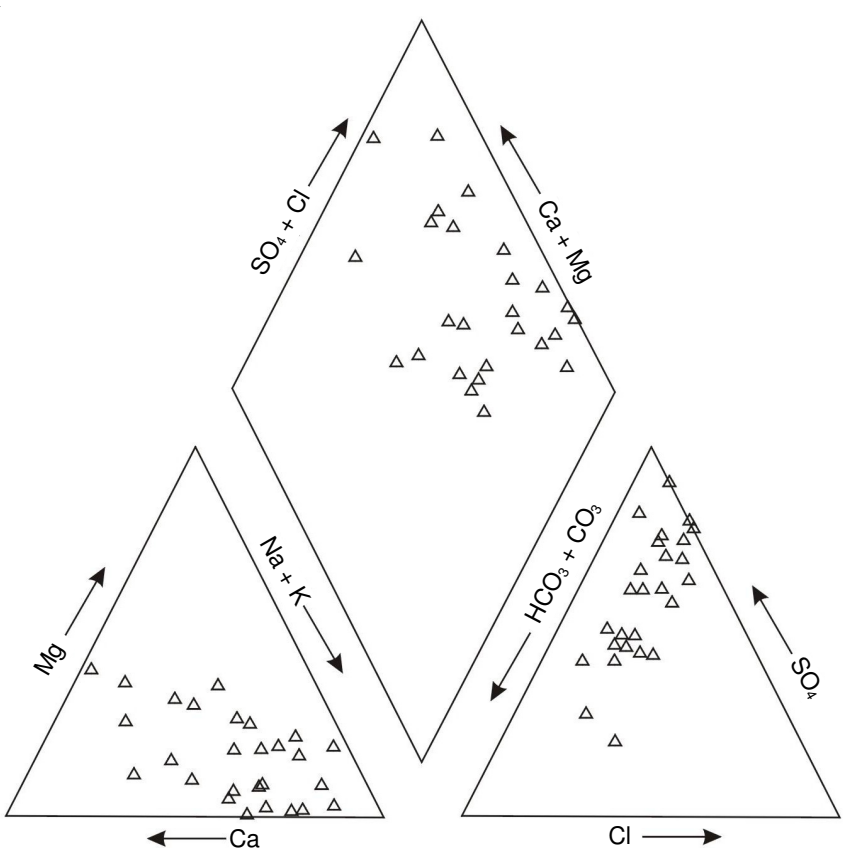

Fig. 2. Piper diagram of groundwater samples

Mineral saturation: SI values of calcite, dolomite and gypsum of groundwater samples are listed in Table-1. As can be seen from the Table, SI values for gypsum of all samples are less than 0 , implying that gypsum is under-saturated and the groundwater can feasibly dissolve gypsum. In contrast, most of the SI values for calcite $(n=18)$ and dolomite $(n=$ 16) are higher than 0 , indicating saturation and precipitation of carbonate minerals including calcite and dolomite.

Groundwater in recharge areas or in the upgrading area of flow systems is always under-saturated with calcite, dolomite and gypsum because of the insufficient mineral sources and/ or disequilibrium of water rock interactions. And thus, groundwater has had prolonged contact with the aquifer may obtain equilibrium with the minerals. Therefore, TDS can be used with the location of samples for deducing the direction of groundwater flow and origin ${ }^{5}$.

It can be concluded from Fig. 3 that the correlation between SI values for calcite and ion concentrations of $\mathrm{HCO}_{3}{ }^{-}$and $\mathrm{Ca}^{2+}$ are not obvious, indicating that calcite did not continue dissolving along the flow path. A similar conclusion can also be made for dolomite from the correlation between $\mathrm{SI}_{\text {Dolomite }}$ and $\mathrm{HCO}_{3}{ }^{-}$, as well as $\mathrm{Ca}^{2+}$ and $\mathrm{Mg}^{2+}$ concentrations. In contrast, $\mathrm{SI}_{\text {Gypsum }}$ values are less than 0, implying the probability of dissolution of gypsum along the flow path. However, the $\mathrm{SI}_{\text {Gypsum }}$ values are negatively correlated with $\mathrm{Ca}^{2+}$ concentrations $\left(\mathrm{R}^{2}\right.$ $=0.45)$, suggesting that the dissolution of gypsum is not active because an active dissolution of gypsum will increase the concentration of $\mathrm{Ca}^{2+}$ and then leading to the positive correlation between $\mathrm{SI}_{\text {Gypsum }}$ values and Ca concentrations. Therefore, the 


\begin{tabular}{|c|c|c|c|c|c|c|c|c|c|c|c|c|}
\hline \multicolumn{13}{|c|}{$\begin{array}{c}\text { TABLE-1 } \\
\text { ANALYTICAL RESULTS }(\mathrm{mg} / \mathrm{L})\end{array}$} \\
\hline ID & $\mathrm{pH}$ & TDS & $\mathrm{Ca}$ & $\mathrm{Mg}$ & $\mathrm{Na}+\mathrm{K}$ & $\mathrm{Cl}$ & $\mathrm{SO}_{4}$ & $\mathrm{HCO}_{3}$ & $\mathrm{CO}_{3}$ & SI-1 & SI-2 & SI-3 \\
\hline 1 & 8.3 & 794 & 46 & 26.6 & 172 & 109 & 318 & 109 & 14.1 & -0.81 & -2.84 & -1.22 \\
\hline 2 & 7.3 & 1379 & 239 & 26.5 & 132 & 98.1 & 580 & 303 & 0 & -0.01 & 0.31 & -2.11 \\
\hline 3 & 7.4 & 1060 & 108 & 11.2 & 195 & 105 & 298 & 343 & 0 & -0.06 & -0.25 & -1.35 \\
\hline 4 & 7.3 & 1322 & 142 & 71.7 & 158 & 93.1 & 720 & 137 & 0 & 0.27 & 0.25 & -1.88 \\
\hline 5 & 8.3 & 996 & 80.8 & 13.2 & 206 & 98.4 & 304 & 283 & 10.1 & 0.35 & 0.48 & -0.4 \\
\hline 6 & 7.3 & 1052 & 124 & 59.4 & 106 & 91 & 465 & 207 & 0 & -0.08 & -0.1 & -1.65 \\
\hline 7 & 7.3 & 1250 & 178 & 33.6 & 150 & 91.2 & 581 & 216 & 0 & -0.25 & 0.13 & -2.02 \\
\hline 8 & 7.3 & 1982 & 80.2 & 54.3 & 439 & 126 & 676 & 607 & 0 & 0.6 & 1.16 & -1.06 \\
\hline 9 & 8.3 & 1473 & 135 & 4.24 & 341 & 158 & 763 & 53.8 & 20.2 & 0.43 & 0.96 & -1.42 \\
\hline 10 & 7.3 & 680 & 25.6 & 2.39 & 196 & 100 & 306 & 48.7 & 0 & 0.47 & 0.31 & -0.63 \\
\hline 11 & 7.3 & 888 & 56.3 & 1.62 & 231 & 107 & 433 & 58.4 & 0 & 0.3 & -0.04 & -1.12 \\
\hline 12 & 8.7 & 2255 & 29.6 & 84.9 & 676 & 93.6 & 1169 & 0 & 38.3 & 0.25 & 0.66 & -1.07 \\
\hline 13 & 7.3 & 1103 & 81.6 & 51.6 & 174 & 103 & 371 & 322 & 0 & 0.55 & -0.08 & -0.75 \\
\hline 14 & 7.5 & 1269 & 93.5 & 77.2 & 159 & 124 & 237 & 578 & 0 & -1.19 & -3.06 & -1.63 \\
\hline 15 & 7.3 & 848 & 31.8 & 32.7 & 190 & 98.7 & 367 & 128 & 0 & 1.88 & 2.3 & -0.29 \\
\hline 16 & 8.7 & 1252 & 260 & 32.4 & 281 & 46.6 & 233 & 329 & 70.5 & -0.29 & -1.35 & -1.13 \\
\hline 17 & 8.8 & 1220 & 103 & 47.3 & 287 & 80.7 & 559 & 109 & 35.3 & 0.55 & 0.86 & -1.34 \\
\hline 18 & 8.7 & 1112 & 153 & 11.5 & 255 & 92.9 & 455 & 0 & 37.1 & -0.7 & -1.06 & -1.53 \\
\hline 19 & 8.6 & 1020 & 39.6 & 14.5 & 289 & 101 & 532 & 0 & 27.8 & 1.94 & 3.34 & -0.98 \\
\hline 20 & 7.3 & 1190 & 97.7 & 14.9 & 241 & 104 & 367 & 366 & 0 & 1.15 & 2.31 & -0.98 \\
\hline 21 & 7.3 & 640 & 94.1 & 40.7 & 30.4 & 99.8 & 91.3 & 284 & 0 & 0.11 & -2.45 & -1.1 \\
\hline 22 & 7.4 & 774 & 69.8 & 23.9 & 133 & 101 & 237 & 209 & 0 & -0.05 & -0.21 & -1.33 \\
\hline 23 & 7.4 & 2567 & 179 & 116 & 455 & 191 & 1399 & 227 & 0 & 0.13 & 0.99 & -1.62 \\
\hline 24 & 7.3 & 1922 & 327 & 90.4 & 126 & 194 & 981 & 204 & 0 & 0.37 & 1.01 & -1.93 \\
\hline 25 & 8.4 & 2339 & 13.4 & 7.26 & 742 & 141 & 1240 & 164 & 30.9 & 0.28 & -0.42 & -1.59 \\
\hline 26 & 8.2 & 2083 & 6.94 & 13.6 & 655 & 224 & 879 & 284 & 20.1 & 0.12 & 0.39 & -0.56 \\
\hline 27 & 7.7 & 849 & 151 & 63.2 & 7.22 & 132 & 271 & 225 & 0 & 0.33 & 0.83 & -1.8 \\
\hline
\end{tabular}
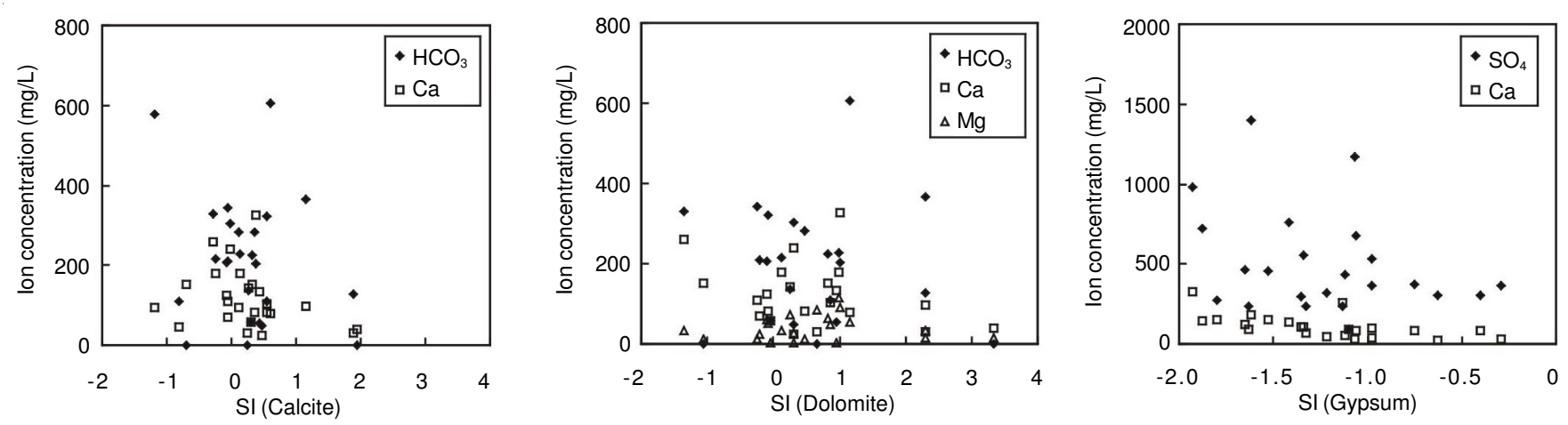

Fig. 3. Plots of SI values versus ion concentrations

dissolution of gypsum is probably limited by the dissolution of calcite and/or dolomite, as well as dissolution and oxidation of pyrite, because they can lead to the increasing of $\mathrm{Ca}^{2+}$ and $\mathrm{SO}_{4}{ }^{2-}$ concentrations and then limit the dissolution of gypsum.

Contributions to TDS: The relationships between TDS and major ions can be useful for interpreting major hydrogeochemical evolution processes within the aquifer and, can also be used to deduce the sources of ions and the origin of the groundwater ${ }^{9}$. For cations in the groundwater samples, there is good linear correlations between $(\mathrm{Na}+\mathrm{K})$ and TDS $\left(\mathrm{R}^{2}=\right.$ $0.75)$, whereas good correlation between $\mathrm{SO}_{4}{ }^{2-}$ and TDS can be obtained for the anions $\left(\mathrm{R}^{2}=0.79\right)$ (Fig. 4). Additionally, $\mathrm{Ca}^{2+}$ and $\mathrm{HCO}_{3}^{-}$(except for three samples with TDS values $=$ 1981,2255 and $2567 \mathrm{mg} / \mathrm{L}$ ), $\mathrm{Mg}^{2+}$ concentrations are slightly increased with increasing of TDS. These correlations suggest that dissolution of $\mathrm{Na}^{+}, \mathrm{K}^{+}, \mathrm{Ca}^{2+}$ and $\mathrm{Mg}^{2+}$ enriched minerals such as albite, K-feldspar, gypsum, calcite and dolomite is important for the increasing of TDS, although the dissolution of gypsum has been probably affected by other processes (see above).

Source of ions: If $\mathrm{Ca}^{2+}, \mathrm{Mg}^{2+}, \mathrm{SO}_{4}{ }^{2-}$ and $\mathrm{HCO}_{3}{ }^{-}$are solely derived from the dissolution of carbonate (calcite and dolomite) and evaporate minerals (gypsum) and if $\mathrm{Na}$ and $\mathrm{Cl}$ are solely from the dissolution of halite, then the ratios between ions such as $(\mathrm{Ca}+\mathrm{Mg}) /\left(\mathrm{SO}_{4}+\mathrm{HCO}_{3}\right)$ and $\mathrm{Na} / \mathrm{Cl}$ would be a constant value of 1 . However, as can be seen from Fig. 5, the values of $\left(\mathrm{Na}^{+}+\mathrm{K}^{+}\right) / \mathrm{Cl}^{-}$of all samples except three are higher than 1 , suggesting other sources of $\mathrm{Na}^{+}$and $\mathrm{K}^{+}$. In combination with the correlation between $(\mathrm{Na}+\mathrm{K})$ and TDS values (Fig. 4), as well as the existence of sandstone in the strata, the high values of $\left(\mathrm{Na}^{+}+\mathrm{K}^{+}\right) / \mathrm{Cl}^{-}$probably suggests the incorporation of albite and/or K-feldspar. 

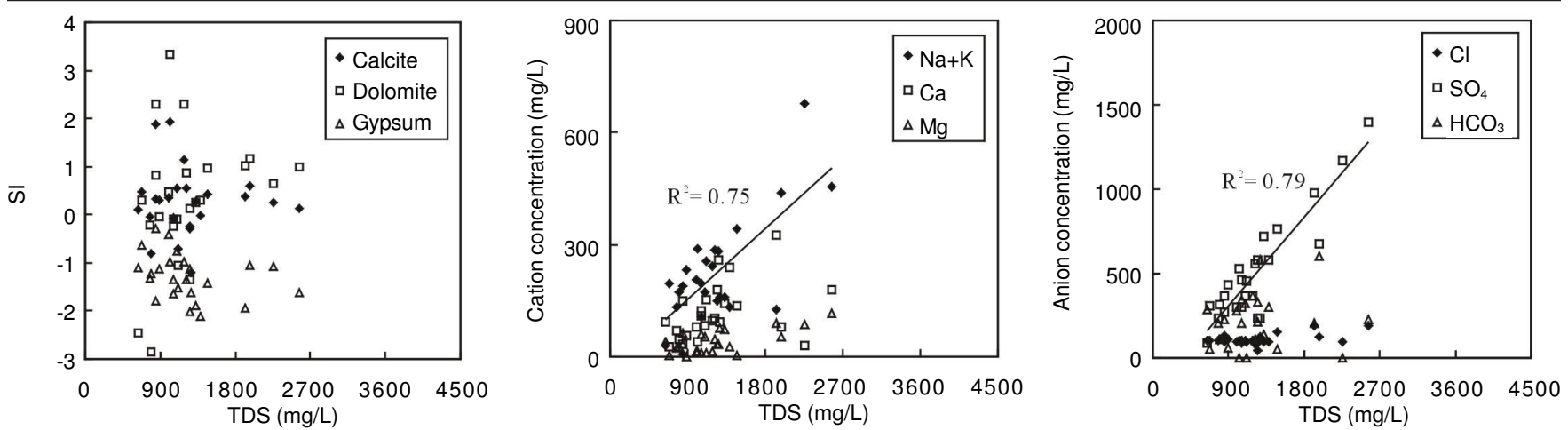

Fig. 4. Plots of TDS versus SI and ion concentrations
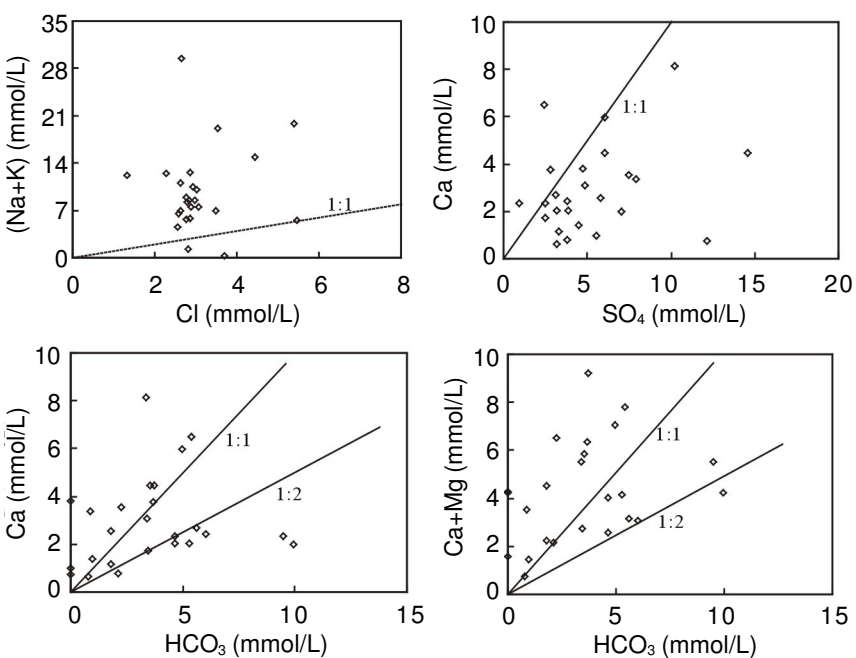

Fig. 5. Plots of ion concentrations

Additionally, if $\mathrm{Ca}^{2+}$ and $\mathrm{SO}_{4}{ }^{2-}$ are originated only from the dissolution of gypsum, then the $\mathrm{SO}_{4}{ }^{2-} / \mathrm{Ca}^{2+}$ will be equivalent to one. The higher $\mathrm{SO}_{4}{ }^{2-}$ concentrations relative to $\mathrm{Ca}^{2+}$ (Fig. 6) suggests that additional $\mathrm{SO}_{4}{ }^{2-}$ are supplied from other sources. Considering about the existence of pyrite in the coal bearing strata, the increasing of $\mathrm{SO}_{4}{ }^{2-}$ concentrations probably originated from the dissolution of pyrite $(\mathrm{FeS})$ and then oxidation of $\mathrm{S}^{2-}$.

Moreover, if calcite is the sole source of $\mathrm{Ca}^{2+}$ and $\mathrm{HCO}_{3}^{-}$, the $\mathrm{Ca}^{2+} / \mathrm{HCO}_{3}{ }^{-}$would be 1:1-1:2. However, as can be seen from Fig. 6, all of the samples can be subdivided into two types, one is $\mathrm{HCO}_{3}{ }^{-}$enriched with $\mathrm{Ca}^{2+} / \mathrm{HCO}_{3}{ }^{-}$less than 0.5 , another one is $\mathrm{Ca}^{2+}$ enriched with $\mathrm{Ca}^{2+} / \mathrm{HCO}_{3}{ }^{-}$higher than 1 . This phenomenon cannot be only produced by dissolution of calcite, but the dissolution of dolomite can increases the concentration of $\mathrm{HCO}_{3}^{-}$whereas the dissolution of gypsum will increase the concentration of $\mathrm{Ca}^{2+}$. This consideration is further confirmed by the correlation between $\left(\mathrm{Ca}^{2+}+\mathrm{Mg}^{2+}\right)$ and $\mathrm{HCO}_{3}^{-}$: samples with $\left(\mathrm{Ca}^{2+}+\mathrm{Mg}^{2+}\right) / \mathrm{HCO}_{3}{ }^{-}$higher than 1 is affected by dissolution of gypsum whereas the samples with ratios between 1 and 0.5 are primarily originated from dissolution of dolomite.

\section{Conclusion}

Chemical compositions (major ions) of groundwater from the Taiyuan Formation aquifer in Liuyi coal mine, northern Anhui Province, China have been measured for evaluating the hydrochemical characteristics of the aquifer, the following conclusion have been made: The groundwater are moderate to highly mineralized with TDS values range from 640 to 2567 $\mathrm{mg} / \mathrm{L}$ and are predominantly composed of $(\mathrm{Na}+\mathrm{K}), \mathrm{Ca}^{2+}$ and $\mathrm{SO}_{4}{ }^{2-}$. Most of the groundwater samples are saturated with calcite and dolomite, whereas the gypsum is under-saturated, their average saturation indexes are $0.25,0.18$ and -1.29, respectively. $\mathrm{Na}^{+}, \mathrm{K}^{+}, \mathrm{Ca}^{2+}$ and $\mathrm{Mg}^{2+}$ enriched minerals such as halite, albite, $\mathrm{K}$-feldspar, gypsum, pyrite, calcite and dolomite are important for the increasing of TDS. $\mathrm{Na}^{+}$and $\mathrm{K}^{+}$ are originated from the dissolution of halite, albite and $\mathrm{K}$ feldspar, $\mathrm{SO}_{4}{ }^{2-}$ is from dissolution of gypsum and the dissolution and oxidation of pyrite, whereas $\mathrm{Ca}^{2+}$ and $\mathrm{Mg}^{2+}$ are originated from dissolution of calcite and dolomite.

\section{ACKNOWLEDGEMENTS}

This work was financially supported by the National Natural Science Foundation of China (41173106).

\section{REFERENCES}

1. P. Huang and J. Chen, J. China Coal Soc., 36, 131 (2011).

2. W. Wei, X. Lu and L. Shi, J. China Coal Soc., 35, 811 (2011).

3. H. Chen, X. Li, A. Liu and S. Peng, Sci. Technol., 40, 1114 (2009).

4. F. Moral, J.J. Cruz-Sanjulian and M. Olias, J. Hydrol., 360, 281 (2008).

5. D. Gastmans, H.K. Chang and I. Hutcheon, Appl. Geochem., 25, 16 (2010).

6. S. Ettazarini, Environ. Geol., 49, 293 (2005).

7. L. Belkhiri, A. Boudoukha, L. Mouni and T. Baouz, Geoderma, 159, 390 (2010).

8. L. Chen, H. Gui and X. Yin, J. China Coal Soc., 33, 1107 (2008).

9. D.L. Parkhurst and C.A.J. Appelo, Geological Survey Water-Resources Investigations Report 99-4259, p. 310 (1999).

9. S.K. Kumar, V. Rammohan, J.D. Sahayam and M. Jeevanandam, Environ. Monitor. Assess., 159, 341 (2009). 